\title{
Language Acquisition of a Mentally Retarded Student at SDLB of Tunas Harapan: Psycholinguistics Study
}

\author{
Heny Sulistyowati ${ }^{1, *}$ Rukminingsih Rukminingsih ${ }^{2}$
}

\author{
1,2 STKIP PGRI Jombang, Indonesia \\ *Corresponding author. Email: heny.sulistyowati@gmail.com
}

\begin{abstract}
A mentally retarded student has an in elegancy function, communication abilities, and social skills that are below average. The goal of this study was to depict a mild mentally retarded student's language acquisition ability at a special Elementary school for mentally retarded (SDLB) in Tunas Harapan Jombang, Indonesia. The relationship between language and mind in processing and creating utterances in language learning for a mentally retarded student was investigated using a psycholinguistics study. A qualitative case study was used in this investigation. The subject was a student at SDLB Tunas Harapan Jombang who was mentally mildly retarded. Psycholinguistics, language acquisition, and phonology were employed as study theories. The information was gathered by field observation with mildly mentally impaired students, which included interviewing, recording, and note-taking approaches. The findings demonstrate that recognizing letters and pronouncing vocabulary while engaging with her teachers' classmates and family has an impact on her speaking skill development.
\end{abstract}

Keywords: Language Acquisition, Mentally Retarded Student, Speaking Ability

\section{INTRODUCTION}

Every child is a one-of-a-kind individual with a distinct developmental pattern, necessitating different treatment. In Indonesia, the number of children with special needs has risen to 1.6 million [1]. Children with special needs aren't just those who are mentally challenged [2]. One of the Children with special needs is disorder adaptation to the environment (mental retardation). One of the problems in language acquisition producing speech is the identification and correction of speech development for children with mental retardation [3].

Understanding, language, language production, and language learning are the three basic objects of research in psycholinguistics. According to [4] stated that there are four main topics in psycholinguistics: a) comprehension, namely the mental processes that humans pass through so that they can catch what people are saying and understand What do you mean; b) production, namely the mental processes in ourselves that enable us to say as we say; and c) neurological, which enables humans to speak; and d) language acquisition, which refers to how humans learn to speak. While psycholinguistic studies include language understanding, language production, and language acquisition, his opinion adds one more object, namely the biological and neurological foundations. Similar previous studies reveal that explains how a child learns language automatically because he or she is equipped with a special language device known as a LAD (Language Acquisition Device)[5];[6] ,\&[7].

Psycholinguistics is a branch of linguistics that combines psychology and linguistics. This science developed in the 1960s in reaction to intellectuals' enthusiasm for Chomsky's work. Psycholinguistics is one of the newest disciplines in cognitive science, focusing on thinking and mental processes related to language comprehension, production, and acquisition [8]

The purpose of this study is to describe the speaking ability of language acquisition for mild mentally retarded students at a special Elementary school for mentally retarded (SDLB) of Tunas Harapan Jombang, Indonesia. This study is therefore part of the field of psycholinguistics. The process of learning a language focuses on mastering one's mother tongue. The data source for this study is mentally retarded children SDLB of Tunas Harapan third grade.

As a result, this study focuses on language learning in mentally retarded children. The reason for focusing this study on language acquisition for mentally retarded children is that many people still do not comprehend what 
mentally retarded children are and many others are uninterested in their development, particularly their language skills. Children with mental retardation have flaws of their own, particularly in terms of cognitive abilities. particularly their language skills.

Mentally retarded children have problems of their own, especially in terms of cognitive capacity. Their verbal abilities, in particular. Studies on retarded mental children have been conducted by some researchers, however, there are few studies to portray speaking ability of language acquisition for a mild mentally retarded student which focus on psycholinguistics, language acquisition, and phonology. Some other researchers focus on the ways how to teach retarded students for vocabulary, reading skills, and writing skills. [6]; [7],[8] and [9].

It is hoped that the finding of this study provides some pedagogical contributions both theoretically and practical significant. The theoretical contribution of this study is supporting language acquisition under psycholinguistics theory of Field, Y. The practical contribution of this study can be implemented to encourage mild mentally retarded students in language acquisition for speaking skill involving phonological awareness as the goal of this study.

According to the American Association on Intellectual and Developmental Disabilities, "intellectual disability is defined by significant restrictions in both intellectual functioning and adaptable behavior, as indicated in conceptual, social, and practical adaptive skills" (AAIDD). This mental condition appears before the age of eighteen. [10]. Mental retardation is a condition characterized by a lack of social communication and limited intelligence in children whose intelligence is significantly lower than the average [11] \& [12].

According to the AAMD (American Association on Mental Deficiency) and PP No. 72 of 1991in [10] mentally impaired children are classified into three groups:

\subsection{Mild mental retardation}

Despite their intelligence and social adaptability being hampered, those who belong to this category have the ability to progress in the areas of academic studies, social adjustment, and work ability. Moron or crippling mental retardation are terms used to describe mild mental retardation. The mildly mentally retarded group, according to Binet, has an IQ of 68-52, while the Weschler Scale has an IQ of 69-55. People with mental disabilities can nonetheless learn to read, write, and do basic math. Mentally handicapped children will be able to succeed on their own if they are given enough and competent supervision and research.

\subsection{Moderate mental retardation}

Despite their intelligence and social adaptability being hampered, members of this category can progress in academic studies, social adjustment, and workability. Moderate mental retardation according to Binet, the mildly mentally retarded group has an IQ 35-49.

\subsection{Severe and Profound mental retardation}

Children with severe mental disability, on the whole, cannot be taught to care for themselves, socialize, or work. Some of them can (to some extent) look after themselves, communicate properly, and adapt to their relatively limited surroundings. Binet defines moderate mental impairment as having an IQ of 20 to 34 .

This group of children with profound mental retardation has a very limited ability to be taught how to care for themselves, socialize, or work. Among them (to a degree), some can care for themselves, communicate clearly, and adapt to their very limited environment.

Psycholinguistics is simply defined as a study of human language/human mind relations [13]. In short, psycholinguistics investigates three important processes: (1) language production, (2) language comprehension, and (3) language acquisition. Developmental psycholinguistics and applied psycholinguistics play a major role in the design of appropriate teaching methods in language teaching. By human physical and mental developments, psycholinguistic theory covered the language development of humans. The theories are taken into account when designing language teaching programs and materials so that second-language learners master the target language effectively.

The psycholinguistic approach can be used as a competence in the field of education. It identified a number of communication difficulties, such as student orientation. It is also psycholinguistic that students' personalities, such as introverts and extroverts, influence their language learning performance [14]. Speaking problems, such as voice disorders, stuttering, and disarticulation, can also be attributed to a personality disorder. [13] This is the first study to establish a link between children's linguistic environment and neurological language processing, identifying both an environmental and a neural mechanism that underpins differences in language ability. Almost every language problem has been solved using a psycholinguistic approach. According to the author [14], the following practical language speaking skills are related to fluency: 1) Generalized phonemes of language; 2) Phoneme paradigmatic structure based on specific characteristics; and 3) Sound images of words, phonemes, and phonemes in sequence. Furthermore, children can self-identify their 
linguistic deviations from language standards through mispronunciation of words or reproduction of content.

As a result, this study focuses on language learning in mentally retarded children. The phrase is used by [15] for children who acquire the first language of their mother tongue and those who learn a second or foreign language (second language). Because many people still don't understand what mentally retarded children are, and many others are uninterested in their development, particularly their acquisition), this study will focus on language acquisition for mentally retarded children. There is no longer any issue in using these terminology. Some professionals refer to language learning as "language learning," while others refer to it as "language learning." [16] explains this by saying that some experts believe that acquiring a second language can be used to teach it intentionally and consciously.

This is in contrast to the first and second languages, which are acquired naturally and unconsciously outside of a formal setting. Because it is assumed to be learnt formally or informally in the second or third language, the term "acquisition of the language" is employed. The term used in this article refers to the acquisition of second language learning. Naturalistic language learning and formal language learning are the two types of language learning. naturalistic language learning is the process of learning a language in an unintentional, conscious, and natural way. $\mathrm{n}$ bilingual or multilingual society, this is more widespread. Formal language learning, on the other hand, takes place in a classroom setting with teachers, resources, and learning supports.

\section{METHODS}

A qualitative case study methodology was used in this study. Case studies, according to [17], are an inquiry approach in which researchers investigate in depth a program, event, activity, process, or one or more individuals. The source of data is the subject from which a study is obtained by the researcher, the student who responds or answers the researcher's questions. The source of the data in this study was one student with mental retardation at SDLB Tunas Harapan Jombang in the third-year class. The object of the research studied was only one student because the student suffered from mild mental retardation. The data in the study were in the form of alphabetic vocabulary, dictate and imitate vocabulary. Through what students did in the aspect of speaking skills that was carried out by a mentally retarded student in third year class at SDLB Tunas Harapan Jombang.

\subsection{Observation}

The observation process was carried out at the beginning of the researcher entering the school by observing the object then the researcher was allowed to choose the object under study her teacher's opinion. The research process was conducted by looking directly at the object to be studied and observing the activities of mentally retarded children.

\subsection{Recording}

Researchers recorded pictures of all conversations made by students starting the learning process and the interview process with researchers. The recording process was carried out using a recording device. Therefore, the researchers recorded all activities related to the observation process at SDLB Tunas Harapan Jombang.

\subsection{Data Transcription}

The data obtained from the recordings were transcribed into notes so that the researchers obtained data in the form of writing. The researcher also saw the results of the notes in the interview and matched them with the results of the time of the recording along with the interview text that had been transcribed into notes at the time of the observation.

\subsection{Data Analysis}

Data analysis was done by identifying the re-reading data. Identification, grouping, description, analysis, and conclusion of results

\section{FINDING}

\subsection{Speaking Skill Description}

Data were obtained by mastering the language skills of SDLB in the third-year class students with a mentally retarded background. The researcher processed the data which are qualitatively analysed in this chapter. The data are in the form of media requests obtained through the process of the conversation and illustrate the students. Received by researchers the following data.

a. Spelling

1. Teacher: What letter of the alphabet is this?

Student:

/a,b,c,d,e,f,g,h,i,j,k,l,m,n,o,p,q,r,s,t,u,v,w,x,y,z/

Cika placed letters on the media board according to their ability to recognize several letters. The letters were posted on the display board, then the teacher explained the letters and imitated objects. Object's ability to recognize letters was quite good because it was able to place letters coherently even though it took a little time to remember to spell the letters of the alphabet. The pronunciation of the letters was good but for the letter $f$ it is pronounced (ep) and the letter q becomes (khi) 


\section{b. Dictation and Picture Description}

1. Teacher : What is this fruit called?

Student : : /a, p,e,1/

Teacher : What color is it??

Student : Tuning

Cika mentioned apples, when the letters of the alphabet said X, Y, Z, but when she said objects she could but when she strung the letters of the alphabet they could not For the mention of the color of apples, the yellow color became tuning.

\section{Teacher : What is this fruit called? \\ Student : : j,e,r,u,k / \\ Teacher :What color is it ? \\ Student :Green}

Cika mentioned apples, when the letters of the alphabet said X, Y, Z, but when she said objects she could but when she strang the letters of the alphabet they could not For the mention of the color of apples, the yellow color became tuning.

\section{Teacher : What is this fruit called? \\ Student : : $\mathrm{b}, \mathrm{a}, \mathrm{l}, \mathrm{i}, \mathrm{m}, \mathrm{b}, \mathrm{i}, \mathrm{n}, \mathrm{g} /$ \\ Teacher : What color is it? \\ Student : it is unclear}

When the object is balimbing, the correct writing for the letters of the alphabet, namely R, T, S, is starfruit. The subject could say fruit, but she could not get the letters to line up properly.

\section{Teacher : What is this fruit called? \\ Student : /d, $, \mathrm{l}, 1, \mathrm{i}, \mathrm{m}, \mathrm{a} /$ \\ Teacher : What color is it ? \\ Student : Grey}

Cika's learning process for the pronunciation of the letters has not been able to turn pomegranate into $\mathrm{O}, \mathrm{N}$, J, S, R, Q, K, M in good writing, it should coherently be PELIMA. The development of subject learning process in compiling the letters of the alphabet has not been able to but to mention the fruit objects on the display board.

c. Dictation in Writing

1. Teacher : what line is it ?

Student : :/t.i.d,u,r/, /l,Ә,n,g,k,u,n,g/, $/ \mathrm{m}, \mathrm{i}, \mathrm{r}, \mathrm{i}, \mathrm{n}, \mathrm{g} /$

The student of this study was able to say according to the selected line, making it easy for her to move her hand to mention multiple lines. It dictated and thicken from slanted lines to curved lines, though the thickening process was messy when she imitated the lines determined by the book. She was an abbreviation for Almanda Cika Salini could recall the names of the lines mentioned in the book, such as sleep lines, curved lines, and slashes.
2. Teacher : What letter of the alphabet is this?

Student : A is similar with B

Teacher : let me give an example

Student : yes

Cika was very happy because she could learn to remember the letters of the alphabet and learn to draw in bold letters. Imitating the letters of the subject's alphabet was not difficult because she was able to write (A) large and (a) small letters well as well as writing (B) large and (b) small letters.

Teacher : What letter of the alphabet is this? Student : $\mathrm{C}$ and D

The student said that the letters C and D were good and correct then, to thicken the letters was also good. Distinguishing uppercase (C) and small (c) letters was a little difficult because they have the same shape, but distinguishing large (D) and small (d) letters is easy. The ability to thicken and dictate her letters has been mastered even though she had to give an example first because of the process of remembering writing and mastering letters that sometimes she forgot.

\section{Teacher : What letter of the alphabet is this? Student $\quad$ E and F}

The development of the object learning process by learning to thicken the large letter (E) she was able to work with the small letter (e) having a little difficulty because of the curve in the small e. The letters $(F)$ were large and (f) were small in thickening the letter, because the writing was almost the same, the only difference was that there was a slight bend in (f) small.

Based on the data above, it can be estimated that Cika's language skills are not significantly different from those of other children. Cika's ability to understand learning is, of course, different from that of other children, thus this does not automatically make Cika a normal child. Phonologically, the articulation is quite clear, although there are often errors in pronouncing objects. Likewise, in morphological abilities, errors often arise. For example, substitution or mentioning in other words, eliminating certain syllables, assimilation, in other words, adding the wrong syllable According to Cika's class instructor, children with mild mental retardation have language skills that are nearly identical to those of normal children, but their intellect capacities differ. According to [11] \& ]8] mildly mentally challenged children nevertheless require additional assistance in understanding and interpreting classroom material. Similarly, previous research reveals that the presence, or even the creation of an environment that uses the target language in question or at least encourages its use on the part of the learner/s may prove vital.

Furthermore, the data suggest that a mildly impaired student is capable of grasping linguistic habits such as phonological and morphological awareness at a young 
age, as early as elementary school. As a result, a mild mentally retarded student needs a longer time to learn and practice many times through learning by doing to form their memory better and she must be happy while on the learning process. [7]; [9]; [5] [6] \& [18] learning occurs when a person recognizes the difference between what he or she is experiencing and what the outside world represents. [13] there is a link between children's linguistic environments and neurological language processing, identifying both an environmental and a neural mechanism that underpins differences in language ability.

\section{CONCLUSION}

Based on the findings of this study on the acquisition of speaking skills for mentally retarded children conducted at SDLB Tunas Harapan Jombang, it is possible to conclude that the acquisition of speaking skills for mentally retarded children carried out at SDLB Tunas Harapan Jombang includes dictating and imitating reading letters, as evidenced by school learning notebooks. This can be seen in the teacher's understanding of the material through the media used to determine how well students have mastered writing and reading skills. Thus, children with mental retardation or mental retardation are intellectual development conditions in which they face obstacles that prevent them from reaching the stage of development properly and optimally when compared to other normal children. Mentally retarded children can be supported from good school learning; however, they must be trained to speak, beginning with consonants and progressing to good pronunciation through media intermediaries, so that they can influence development in school learning activities.

\section{REFERENCES}

[1] Badan Pusat Statistik,Statistik Indonesia, Jakarta: BPS, 2020.

[2] Heward C.L. Exceptional Children: An Introduction to Special Education, Pearson,2018.

[3] Boriak, O. 2015 Language and speech functional system under development pathologies (mental retardation). Int J. of Ped. Innov and New Tech. 2 (1), 69-75, https://doi.org/10.5604/23920092.1159142

[4] Dardjowidjojo, S. 2016 Psikolinguistik: Pengantar Pemahaman Bahasa Manusia. Jakarta: Yayasan Pustaka Obor.

[5] Astri, Z., \& Wahab 2019 The use of TPR method for disable students with different learning styles in English vocabulary development. SELTICS, 2(2), $66-75,2019$ retrieved from https://ejournals.umma.ac.id/index.php/seltics/artic le/view/336

[6] Widodo. S. 2019 Teaching mild mentally retarded children using augmented reality. Inter $J$ of Learning Teaching and Edu. Research, 18 (7), 184199, https://doi.org/10.26803/ijlter.18.7.12

[7] Barbra, M \& Joyline, N., 2014 The Inclusion of children with mental disabilities: A teachers'rspective. IJHSSE,1 (1). 65-75, retrieved from https://www.arcjournals.org

[8] Sumarlam \& Saddhono, K. 2018 Language acquisition of children with mental disabilities in Pacitan, Hum. J.17(1), 26-36, https://doi.org/10.24036/humanus.v17i1.8542

[9] Nostalgianti, N., 2020 Teacher's strategies and classroom management techniques in teaching English at SMP Inklusi Tpa Jember. LEEA J.4 (1), 177- 187, https://doi.org/10.31539/leea.v4i1.1417

[10] Hallahan, D.P., Kauffman, J.M., \& Pullen, P.C. 2009 Exceptional Learners, Eleventh Edition. New Jearsey: Pearson,

[11] Suprih Widodo; Nur Azizah; \& Trisno Ikhwanudin 2019 Teaching mild mentally retarded children using augmented reality. Inter. J. of Learning, Teaching and Edu. Research, 18 (7), 184-199, https://doi.org/10.26803/ijlter.18.7.12

[12] Atmajaya, D. 2017 Implementasi augmented reality untuk pembelajaran interaktif. J. Ilkom, 9(2). 227 332. https://doi.org/10.33096/ilkom.v9i2.143.227. $\underline{232}$

[13] Romeo RR, Leonard JA, Robinson ST, et al. 2018 Beyond the 30-millionword gap: childen's conversational exposure is associated with language-related brain function. Psychol Sci. J. 29(5):700- 710 . https://doi.org/10.1177/0956797617742725

[14] Purba, N. 2018 Psycholinguistics In Language Learning And Teaching N. Tell J. 6(1), 47-54 http://dx.doi.org/10.30651/tell.v6i1.2077

[15] DeVeney S, Cress CJ, Lambert M. 2016 Parental directiveness and responsivity toward young children with complex communication needs. Int $J$ Speech Lang Pathol. 18(1), 53-64. https://doi.org/10.3109/17549 507.2015.1081282

[15] Field, J. 2004 Psikolinguistics. The Key Concept, Routledge.

[16] Chaer, A. 2015 Psikolinguistik: Kajian Teori,PT Rineka Cipta. 
[17] Creswell, J. W. 2013 Qualitative Inquiry and Research Design: Choosing among Five Approaches, (3rd ed.). Thousand Oaks, CA: Sage.
[18] Salim, J.A \& Mehawesh 2014 Stages in language acquisition: A case study. English Lang. and Lit. Studies $\quad J ., \quad \mathbf{4}, \quad \mathbf{( 4 )}, \quad 16-24$, http://doi.org/10.5539/ells.v4n4p16 